\title{
Identification of homogeneous rainfall regimes in parts of Western Ghats region of Karnataka
}

\author{
B Venkatesh* and Mathew K Jose** \\ National Institute of Hydrology, Hanuman Nagar, Belgaum 590 001, Karnataka, India. \\ *e-mail: bvenki30@yahoo.com \\ **e-mail: mathewkjose@yahoo.com
}

\begin{abstract}
In view of the ongoing environmental and ecological changes in the Western Ghats, it is important to understand the environmental parameters pertaining to the sustenance of the region. Rainfall is one such parameter governing the hydrological processes crucial to agriculture planning, afforestation and eco-system management. Therefore, it is essential to understand rainfall distribution and its variation in relevance to such activities. The present study is an attempt to gain in-depth understanding in this direction. The study area comprises of one coastal district and its adjoining areas in Karnataka State. Mean annual rainfall data of 93 rain gauge stations distributed over the study area for a period of 10-50 years are used for the study. In order to assess the variation of rainfall across the ghats, several bands were constructed parallel to the latitudes to facilitate the analysis. The statistical analyses conducted included cluster analysis and analysis of variance. The study revealed that there exist three distinct zones of rainfall regimes in the study area, namely, Coastal zone, Transition zone and Malanad zone. It is observed that, the maximum rainfall occurs on the windward side ahead of the geographical peak. Further, mean monthly rainfall distribution over the zones has been depicted to enable agricultural planning in the study area.
\end{abstract}

\section{Introduction}

Since the Western Ghats region has been undergoing environmental changes due to various development activities, it is essential to monitor the parameters governing the ecological and environmental equilibrium. Towards achieving this goal, rainfall which is one of the most important parameters for the hydrological regime, needs to be studied in space and time. However, the real issue is in the proper understanding of the nature of the rainfall distribution and variability on a local scale. In a mountainous region, where orography is irregular, rainfall features are also irregular and complex with respect to time and space. The physiographical features force the monsoon current to rise when it encounters with the barriers across the wind flow and results in orographic precipitation. However, such generalized information does not give details on the distribution of rainfall over time and space.

The Western Ghats form a major barrier to the south-west monsoonal current on the west coast. It is well acknowledged that the Western Ghats enhance rainfall activity substantially under favourable conditions, with increasing trend on the windward and decreasing pattern on the leeward side. The maximum rainfall appears to occur in the high altitudinal zones (Sarkar 1967; Patwardhan and Asnani 2000). Due to such variation in the rainfall pattern, homogeneity in rainfall distribution cannot be expected over the Western Ghat region. Instead, it is necessary to identify several geographical zones of coherent rainfall regimes. There have been attempts in the past to identify such zones over the western coastal region as well as in other parts of the country (Gadgil et al 1988; Kulkarni and Reddy 1994). These classifications

Keywords. Western Ghats; rainfall regime; non-dimensional rainfall; orography; bands; cluster analysis; rainfall variation. 
are essential for in-depth understanding of the rainfall variations within each zone to facilitate agriculture planning and management. The sustenance of agriculture derived either from self-sufficiency or from complementary interaction between adjacent agro-climatic regions with closely knit economy relations, is an important issue in the developing world (Gunnell 1997b). In view of this, we attempt to make an analysis of the effect of orography on the distribution of rainfall over parts of Western Ghats. The analysis has been done using the mean annual rainfall for selected stations in the Uttara Kannada district and also covering parts of adjoining districts of Dharwad, Haveri and Shimoga of Karnataka. The mean annual values computed differ from that of normal rainfall values reported by IMD as the length of the data record differs for different areas. The study area covers the windward and leeward sides of the Western Ghat.

\section{Study area}

The Western Ghat forms a range of mountains in peninsular India running approximately parallel to the west coast and is home to the largest tracts of moist tropical forest in the country. The study area, bound between latitude $13^{\circ} \mathrm{N}$ to $15^{\circ} \mathrm{N}$ and longitude $74^{\circ} \mathrm{E}$ to $76^{\circ} \mathrm{E}$, comprises the Uttara Kannada District, and parts of adjoining districts of Dharwad and Shimoga of Karantaka state (figure 1). The orographic features of the study area vary from low to steep gradients sprawling from south to north (Ramachandran and Banerjee 1983).

The general climate in the study area may be classified as tropical monsoon, a wet and dry climate but with only a brief dry season. It is rainfall that primarily determines the nature of the vegetation (Bonell 1997). The annual rainfall is as high as $4000 \mathrm{~mm}$ in the coastal zone which is characterized by steep gradients and good forest cover. This zone is more exposed to monsoon currents. East of the crest line of the ghats are rolling hills with forested slopes and shallow valleys with cultivation. This region (Malanad zone), receives an annual rainfall of $2500 \mathrm{~mm}$ (Lele and Hegde 1997). Away from the crest line, the annual rainfall can be as low as $900 \mathrm{~mm}$ in Transition zone which is predominantly agricultural area. The bulk of the rainfall occurs during the monsoon season (June to September) which accounts for about $80 \%$ of the annual total. The annual temperature varies between $20^{\circ}$ to $38^{\circ} \mathrm{C}$ in Coastal, $20^{\circ}$ and $27^{\circ} \mathrm{C}$ in Malanad and $20^{\circ}$ and $35^{\circ} \mathrm{C}$ in the transition zone.

The study area has a fairly good network of rain gauge stations maintained by the Water Resources Development Organisation (WRDO), Govt. of Karnataka and Indian Meteorological Department.

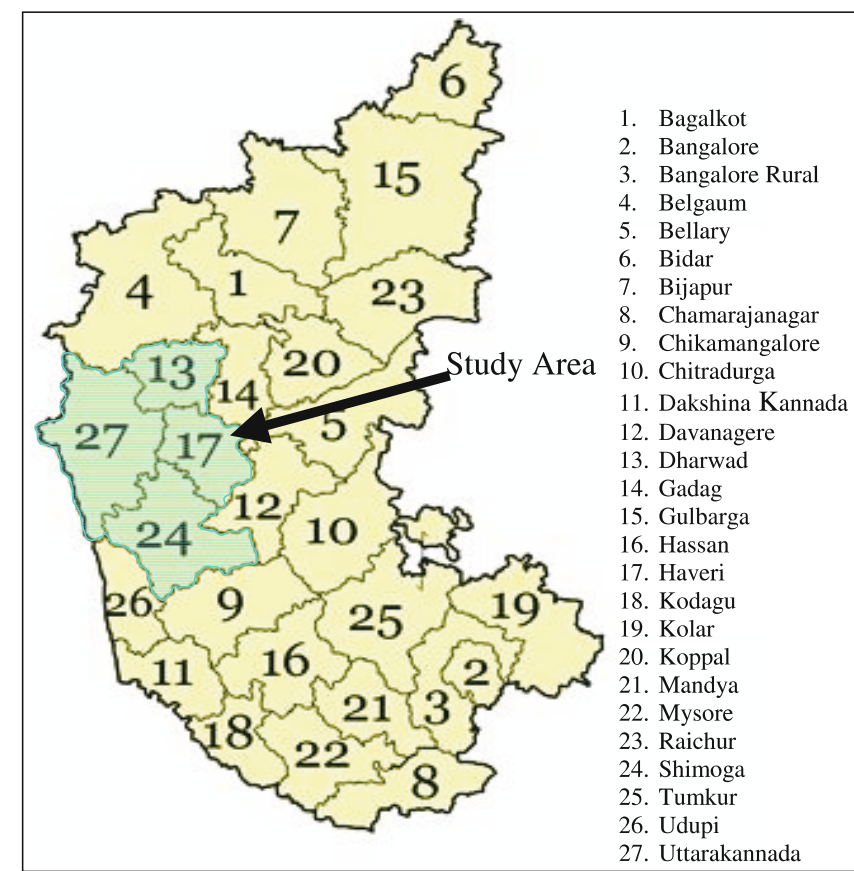

Figure 1. Index map of the study area comprising Uttara Kannada district, parts of adjoining districts of Dharwad and Shimoga of Karnataka State.

\section{Data and methodology}

In the present analysis, 93 rain gauge stations distributed over the region were considered. The data record varies from 10 to 50 years. The rainfall data of these stations have been subjected through primary and secondary validation using standard procedures (HYMOS 1999).

It may be noted that most of the studies (Raghavan 1964; Raju 1981; Ramachandran and Banerjee 1983; Gunnell 1997a; Patwardhan and Asnani 2000) have adopted a regional approach in analyzing rainfall variability. However, in the present study, we have adopted a discrete approach to analyse the rainfall regime. Here the study area has been gridded into a spatial resolution of $15^{\prime}$ latitude by $15^{\prime}$ longitude cells and rainfall values have been assigned to cells. Further, in order to capture the actual variation of rainfall across the Western Ghat, the area covering the windward side of the mountainous part has been sub-divided in to finer grid cells (i.e., $7.5^{\prime} \times 7.5^{\prime}$ ), as shown in figure 2 . It is intended to assess the variation of rainfall along the parallels on several bands ranging from west coast towards the eastern portion of the study area (covering the windward and leeward side of the Western Ghats).

For the purpose of analysis, the mean rainfall of each grid cell was computed. When more than one station falls within a grid cell, either the most reliable station with longer record has been retained 
$75^{\circ}$

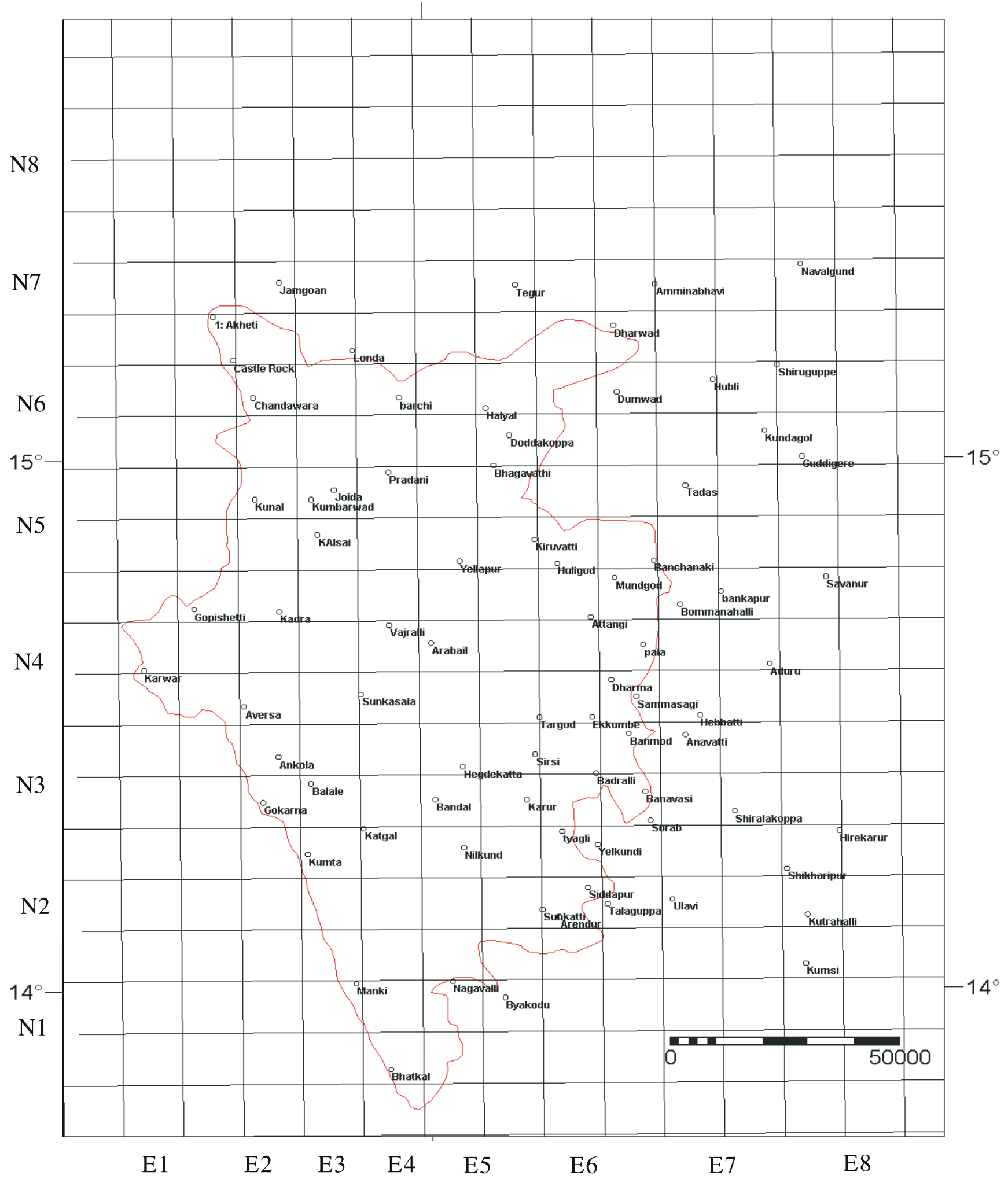

Figure 2. Discretization, grid nomenclature and location of rain gauges in the study area; E1, ..., E8, represents longitudinal division and $\mathrm{N} 1, \ldots, \mathrm{N} 8$ represents latitudinal division at $15^{\prime}$ by $15^{\prime}$ grid interval.

or the average of stations with sufficient periods of common record has been taken. This enables us to assign unique mean rainfall values to each grid cell. Accordingly, the grid cells have been denoted with a nomenclature as indicated in figure 2 . It is noticed that, the usage of longer records for some 


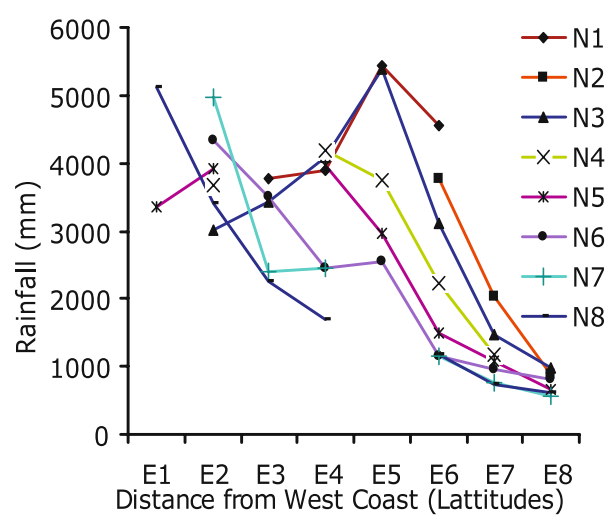

Figure 3. Plot of band-wise rainfall versus distance from west coast.

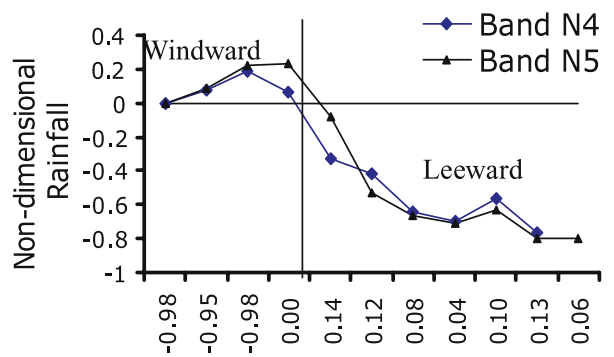

Non-dimensional Elevation

Figure 4. Plot of non-dimensional rainfall versus elevation for band N4 and band N5.

grid cells does in no way affect the veracity of the analyses presented as we are interested in the distributional and variational aspects of rainfall.

Subsequently, the analysis has been carried out along different bands (N1, N2, .., N8) by comparing the rainfall variation along the respective bands covering the windward and leeward sides of the Western Ghats. Further, cluster analysis of the mean rainfall values of the grid cells has been carried out to identify distinct groups of rainfall regimes. Analysis of variance has been performed to ascertain the statistical significance of the thus identified groups.

\section{Results}

It is observed that there is a general agreement in the rainfall distribution with respect to the topographical features, particularly the elevation. Hence, the pattern of rainfall distribution with respect to elevations has been analysed in the following manner.

The analysis has been carried out band-wise over the eight bands starting from the south to the north of the study area. The bands are indicated with notation of N1, N2, ., N8 along the parallels.

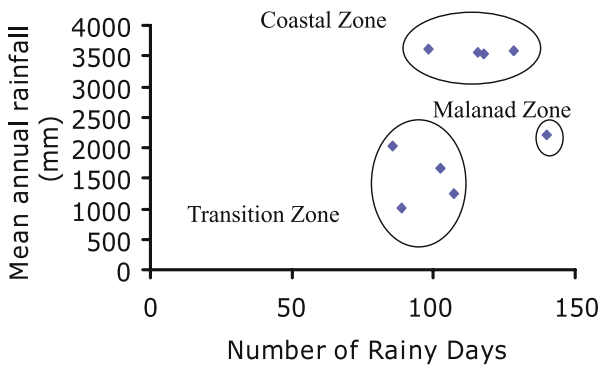

Figure 5. Clusters of mean annual rainfall identifying different homogeneous rainfall zones along the band N5.

\begin{tabular}{|c|c|c|c|c|c|c|c|c|c|c|}
\hline Dec & & & xxxx & \multicolumn{2}{|c|}{$\mathrm{XXXX}$} & \multicolumn{2}{|l|}{ XXXX } & & & \\
\hline Nov & 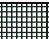 & 盘 & 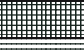 & \multicolumn{2}{|c|}{ 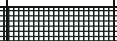 } & 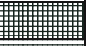 & \multicolumn{2}{|c|}{ 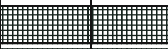 } & 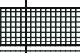 & 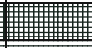 \\
\hline Oct & & & & & & & & & & \\
\hline Sept & & & & & & & & & & \\
\hline Aug & & & & & & & & & & \\
\hline July & & & & & & & & & & \\
\hline June & & & & yyy & yyy & & & & & \\
\hline May & & & & & & 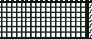 & & 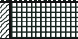 & 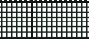 & 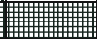 \\
\hline Apr & & & 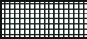 & & & 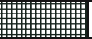 & XXXX & $\mathrm{XXXX}$ & 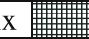 & $\mathrm{XXXX}$ \\
\hline Mar & & & & $\mathrm{XxX}$ & & $\operatorname{xxxx}$ & & & & \\
\hline Feb & & & & & & & & & & \\
\hline Jan & & & & & & & & & & \\
\hline & $\begin{array}{l}\frac{\pi}{0} \\
\frac{3}{4}\end{array}$ & 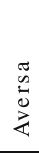 & 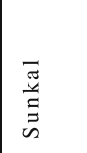 & 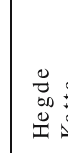 & & $\begin{array}{l}\bar{b} \\
\bar{c}\end{array}$ & 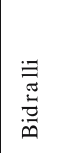 & $\begin{array}{l}\overrightarrow{0} \\
\underline{\Xi} \\
\vec{z} \\
\text { y }\end{array}$ & $\begin{array}{c}\tilde{\sigma} \\
\underset{\Xi}{\tilde{\sigma}} \\
\stackrel{\Xi}{0}\end{array}$ & $\begin{array}{l}\overrightarrow{b 0} \\
\tilde{\sigma} \\
\tilde{\Xi} \\
\Xi \\
\tilde{\Xi} \\
\tilde{n}\end{array}$ \\
\hline \begin{tabular}{|l|}
$>10$ \\
00 \\
$\mathrm{~mm}$ \\
\end{tabular} & $\begin{array}{l}800 \\
100 \\
\mathrm{~m} \mathrm{~m} \\
\end{array}$ & & $\begin{array}{l}600- \\
800 \\
\mathrm{~m} \mathrm{~m}\end{array}$ & $\begin{array}{l}400- \\
600 \\
\mathrm{~mm}\end{array}$ & $\begin{array}{l}200- \\
400 \\
\mathrm{~m} \mathrm{~m}\end{array}$ & $\begin{array}{l}100- \\
200 \\
\mathrm{~m} \mathrm{~m}\end{array}$ & $\begin{array}{l}50- \\
100 \\
\mathrm{~mm}\end{array}$ & $\begin{array}{l}25- \\
50 \\
\mathrm{~m} \mathrm{~m}\end{array}$ & $\begin{array}{l}10-25 \\
\mathrm{~mm}\end{array}$ & $\begin{array}{l}<10 \\
\mathrm{~mm}\end{array}$ \\
\hline & yy. & & & & & & & 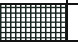 & $\mathrm{XXXX}$ & \\
\hline
\end{tabular}

Figure 6. Distribution of monthly rainfall from the west coast towards interior along a representative band (band N5).

The division along the longitudes are indicated by $\mathrm{E} 1, \mathrm{E} 2, \ldots, \mathrm{E} 8$. The rainfall patterns in the bands are plotted in figure 3 , wherein distance from the coast is on the abscissa and mean rainfall values of the grid cell are as ordinates. These plots can aid in inferring the rainfall distribution pattern in each of the bands. For example, in band N5, it may be noted that the rainfall is incremented with respect to elevation reaching a peak value of $3950 \mathrm{~mm}$ corresponding to the maximum elevation in that band. Subsequently, it can be noted that there is a sharp decrease in the rainfall value corresponding to the fall in elevation. It can be inferred that, the rise in the rainfall is on the wind-facing side and the decrease in the rainfall corresponds to the leeward side of the Western Ghats. This observation conforms with the reported orographic influence on the rainfall distribution.

Further, non-dimensional values of rainfall have been computed using the ratio $\left[\left(P_{i}-P_{b}\right) / P_{b}\right]$, where $P_{i}$ are cell values and $P_{b}$ is the base cell value corresponding to the highest elevation. Similarly, non-dimensional elevational values were 


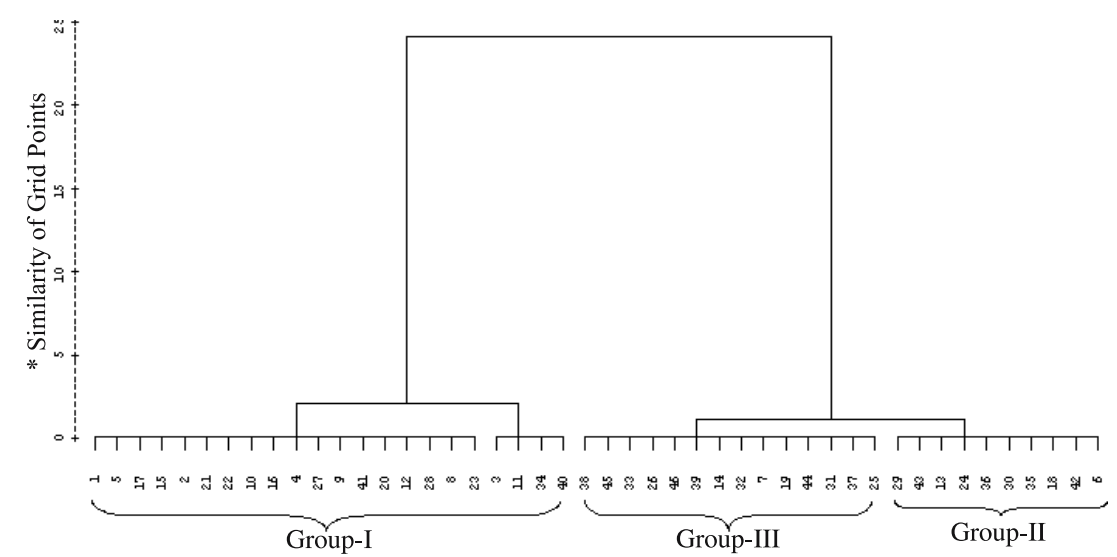

Figure 7. Classification of homogeneous rainfall regimes using the ward clustering method; three rainfall regimes are identified as Group-I, Group-II and Group-III, representing, Coastal, Malanad and Transition zones respectively.

also assigned. The non-dimensional values of rainfall versus elevation are plotted as shown in figure 4 , to elaborate the variability of rainfall with respect to elevation. In these plots the domains of the bands are typically divided into windward and leeward portions by virtue of the ordinate through $X=0$. Also, the rising and falling sections of the rainfall over a band across the terrain are partitioned by the line, $Y=0$. On the windward side, the rising trend is obvious, while after crossing the peak, the trend falls gradually. The sharply declining trend is visible towards the plains of the rain shadow region. However, it is observed that the maximum rainfall value does not always correspond to the geographic peak as the rain gauge network is sparse in the higher altitudes. This fact may explain away the non-coincidence of the maxima of the plot with the vertical line indicating the maximum elevation of the band.

From figure 5, it may be noted that there are three distinct zones of rainfall regimes across the bands, viz.,

- zone consisting of coastal and wind facing portion of the mountains (Coastal zone),

- the zone consisting of the plains of leeward side (Transition zone), and

- the zone consisting of peaks and fringes of the leeward side (Malanad zone).

The spatial and temporal distribution of rainfall across these zones in a typical band has been plotted in figure 6. Figure 6 depicts the distribution of monthly rainfall in band no. 5. Also, it is noticed that a shorter dry period as we progress from coastal region to the malanad region. The Transition zone, however, has the benefit of north-east monsoon, hence there is a little dry period compared to that of the coastal region.

A plot of rainy days against the mean rainfall of the grid cells of a specific band (band 5), distinctly identifies the three clusters (figure 5). These clusters correspond to the thus identified zones. Further, in order to ascertain the statistical significance of the identified zones, a cluster analysis has been carried out with grid averaged rainfall values using the Ward method of clustering with square of Euclidean distance as the measure of distance between pairs of grids. The resulting dendrogram is shown in figure 7 , with the labels of grid averaged rainfall (respective grid numbers) along the $\mathrm{X}$-axis and percentage similarity along the $\mathrm{Y}$ axis. There are three clear zones of rainfall regimes indicated in the dendrogram as Group I, Group II, and Group III. Examining the grid labels, it is found that Group I consists of rainfall values corresponding to the grid cells falling in the coastal and wind-facing portion of the mountain. Similarly, Group II and Group III corresponds respectively to the Malanad and Transition zones of the study area.

The zones thus identified are depicted on the grid map shown in figure 8. Further, the zonal average, standard deviation and coefficient of variation of rainfall in the identified zones are plotted in figure 9. It may be noticed that, the highest rainfall occurs in the coastal zone with the average value of $3964 \mathrm{~mm}$ followed by $1932 \mathrm{~mm}$ in the Malanad zone and $904 \mathrm{~mm}$ in the Transition zone respectively (Table 1). The consistency of the zonation is cross-verified by computing the coefficients of variation within the zones which vary between $18 \%$ and $25 \%$ only.

In order to check the statistical significance of the groups thus identified, a one-way analysis of variance (ANOVA) test was performed between the groups with the null hypothesis that there is a significant difference between the groups. From the results of the test given in table 2 , it may be seen that the mean difference between the groups are significant at $1 \%$ level of significance. 


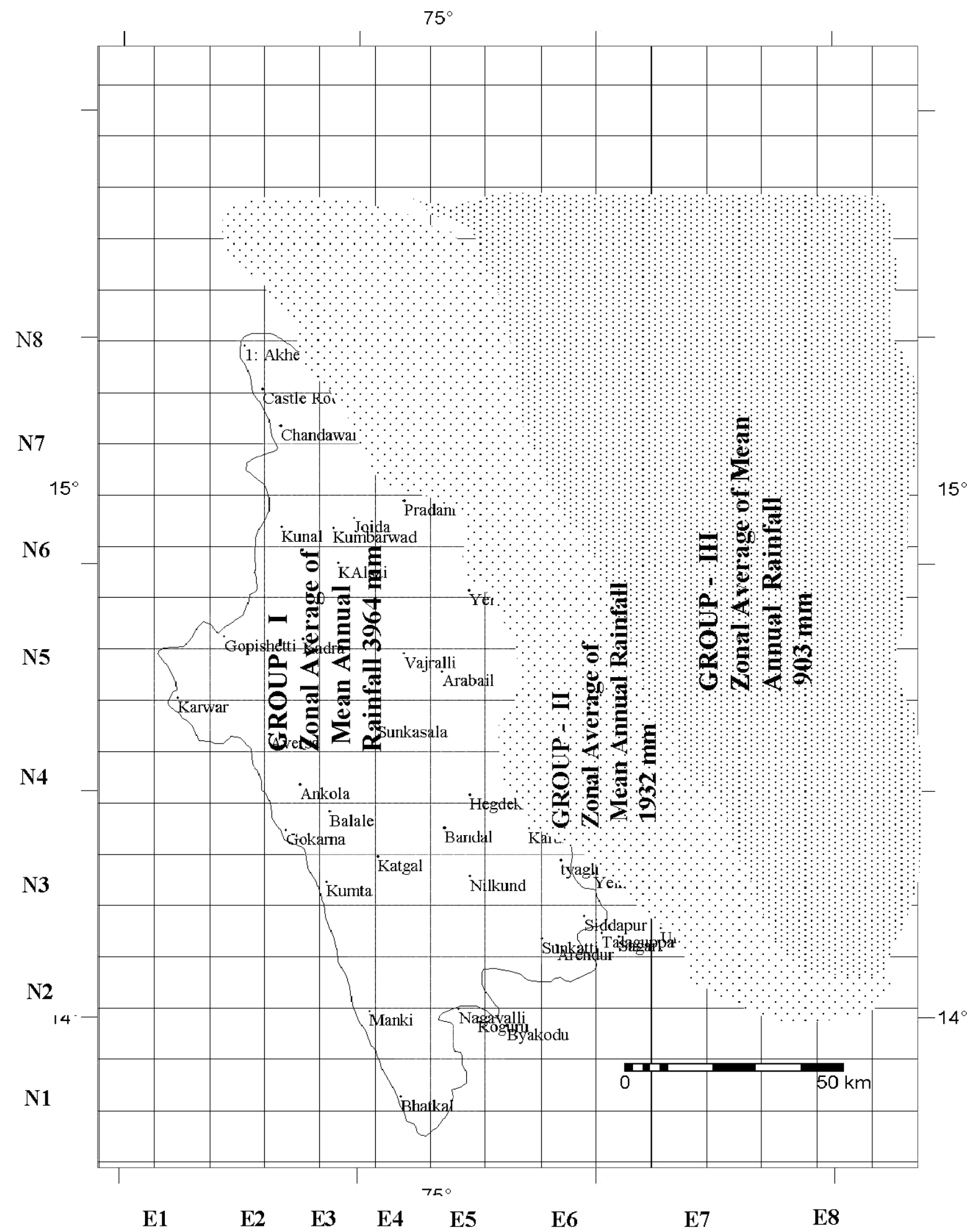

Figure 8. Representation of the identified homogeneous rainfall regions in the study area.

\section{Discussion and conclusion}

In order to study the rainfall variability across the Western Ghat region of Karnataka, Uttara Kannada and parts of Dharwad, Haveri and Shimoga districts adjoining the west coast were selected.
The analysis focused on the mean annual rainfall of the region distributed over the grids designed for the purpose. The relative distribution of rainfall over the region has been analysed band-wise. Various statistical analysis like, cluster analysis and ANOVA were also performed on the annual rainfall 

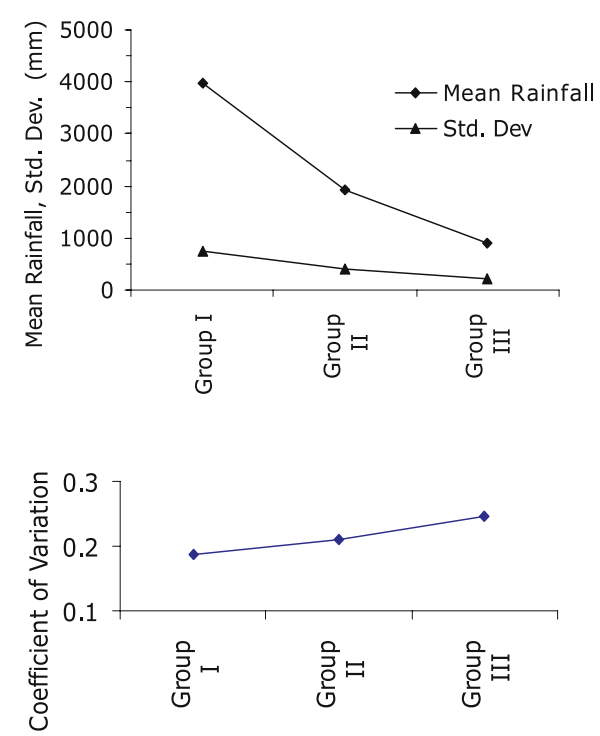

Figure 9. A plot of mean, standard deviation and coefficient of variation of rainfall in the identified homogenous rainfall regions. regime. The analysis revealed that there are three distinct rainfall zones over the study area demarcating Coastal, Malanad and Transition zones with respect to the amount of rainfall. The plot of rainy day with rainfall amount also indicates these zones as separate clusters (figure 5). Further an annual rainfall distribution mosaic (figure 6) has been constructed to depict monthly rainfall variation across a representative band (band N5) of the study area. This kind of representation will be of use in crop planning as well as in the management of agricultural activities in the study area.

The quantum of rainfall is found to be highest in the Coastal zone and lowest in the Transition zone. The fact that the study area is characterized by the presence of hills/peaks of undulating nature implies that orography plays an important role in the rainfall distribution over the region. Therefore, the steadily increasing trend in rainfall distribution observed in the Coastal zone can be attributed to the orographic effect (figure 3) on

Table 1. Details of the groups identified through cluster analysis.

\begin{tabular}{|c|c|c|c|c|c|}
\hline $\begin{array}{c}\text { Sample } \\
\text { no. }\end{array}$ & $\begin{array}{c}\text { Grid } \\
\text { specification }\end{array}$ & Longitude & Latitude & Elevation & Rainfall \\
\hline \multicolumn{6}{|c|}{ Group I } \\
\hline 1 & N1E3 & 43.75 & 12.5 & 12.00 & 3770.12 \\
\hline 2 & N1E4 & 56.25 & 12.5 & 63.66 & 3886.27 \\
\hline 4 & N1E6 & 87.5 & 12.5 & 718.8 & 4547.59 \\
\hline 5 & N2E6 & 87.5 & 37.5 & 574.83 & 3771.76 \\
\hline 8 & N3E2 & 31.25 & 62.5 & 10.4 & 3002.64 \\
\hline 9 & N3E3 & 43.75 & 62.5 & 25.25 & 3439.69 \\
\hline 10 & N3E4 & 56.25 & 62.5 & 15.2 & 4094.48 \\
\hline 12 & N3E6 & 87.5 & 62.5 & 483.97 & 3109.51 \\
\hline 15 & N4E2 & 31.25 & 87.5 & 36.4 & 3664.43 \\
\hline 16 & N4E4 & 56.25 & 87.5 & 50 & 4178.5 \\
\hline 20 & N5E1 & 12.5 & 112.5 & 21 & 3347.26 \\
\hline 17 & N4E5 & 68.75 & 87.5 & 744.3 & 3756.94 \\
\hline 21 & N5E2 & 31.25 & 112.5 & 10.5 & 3911.43 \\
\hline 22 & N5E3 & 43.75 & 112.5 & 628 & 3957.87 \\
\hline 23 & N5E5 & 68.75 & 112.5 & 540.78 & 2952.1 \\
\hline 27 & N6E2 & 31.25 & 137.5 & 735.42 & 4345.26 \\
\hline 28 & N6E3 & 43.75 & 137.5 & 662.23 & 3157.75 \\
\hline 41 & N8E2 & 31.25 & 187.5 & 692 & 3413.86 \\
\hline 3 & N1E5 & 68.75 & 12.5 & 610.90 & 5433.447 \\
\hline 11 & N3E5 & 68.75 & 62.5 & 547.7 & 5376.29 \\
\hline 34 & N7E2 & 31.25 & 162.5 & 579.62 & 4983.13 \\
\hline \multirow[t]{4}{*}{40} & N8E1 & 12.5 & 187.5 & 619.81 & 5121.83 \\
\hline & & & & Mean & 3964.64 \\
\hline & & & Stand & deviation & 742.72 \\
\hline & & & Coefficien & variation & 0.19 \\
\hline \multicolumn{6}{|c|}{ Group II } \\
\hline 29 & N6E4 & 56.25 & 137.5 & 766.87 & 1637.24 \\
\hline 43 & N8E4 & 56.25 & 187.5 & 637 & 1690.01 \\
\hline 13 & N3E7 & 112.5 & 62.5 & 594.48 & 1481.3 \\
\hline 24 & N5E6 & 87.5 & 112.5 & 549.61 & 1505.37 \\
\hline 36 & N7E4 & 56.25 & 162.5 & 480.00 & 1544.88 \\
\hline
\end{tabular}


Table 1. (Continued).

\begin{tabular}{rccccc}
\hline $\begin{array}{c}\text { Sample } \\
\text { no. }\end{array}$ & $\begin{array}{c}\text { Grid } \\
\text { specification }\end{array}$ & Longitude & Latitude & Elevation & Rainfall \\
\hline 30 & N6E5 & 68.75 & 137.5 & 549.86 & 2540.55 \\
35 & N7E3 & 43.75 & 162.5 & 512.06 & 2400.53 \\
18 & N4E6 & 87.5 & 87.5 & 604.92 & 2224.95 \\
42 & N8E3 & 43.75 & 187.5 & 652 & 2262.64 \\
6 & N2E7 & 112.5 & 37.5 & 625.14 & 2037.30 \\
& & & & Mean & 1932.48 \\
& & & Standard deviation & 405.04 \\
& & & Coefficient of variation & 0.21 \\
Group III & & & & \\
38 & N7E7 & 112.5 & 162.5 & 611.02 & 752.39 \\
45 & N8E7 & 112.5 & 187.5 & 658.9 & 731.922 \\
33 & N6E8 & 137.5 & 137.5 & 618.43 & 800.609 \\
26 & N5E8 & 137.5 & 112.5 & 568.03 & 653.153 \\
46 & N8E8 & 137.5 & 187.5 & 579.10 & 610.59 \\
39 & N7E8 & 137.5 & 162.5 & 637.18 & 561.87 \\
14 & N3E8 & 137.5 & 62.5 & 603.98 & 979.477 \\
32 & N6E7 & 112.5 & 137.5 & 605.34 & 948.374 \\
7 & N2E8 & 137.5 & 37.5 & 677.59 & 881.41 \\
19 & N4E7 & 112.5 & 87.5 & 588.16 & 1174.56 \\
44 & N8E6 & 87.5 & 187.5 & 724.5 & 1178.62 \\
31 & N6E6 & 87.5 & 137.5 & 514.22 & 1162.61 \\
37 & N7E6 & 87.5 & 162.5 & 514.60 & 1148.15 \\
25 & N5E8 & 112.5 & 112.5 & 581.06 & 1071.29 \\
& & & & Mean & 903.93 \\
& & & Standard deviation & 221.99 \\
& & & Coefficient of variation & 0.25 \\
\hline & & & & &
\end{tabular}

Table 2. Results of one-way ANOVA test.

\begin{tabular}{cccccc}
\hline & & Mean difference & Standard & \multicolumn{2}{c}{ Confidence interval (99\%) } \\
\cline { 5 - 6 } Sl. no. & Group & between groups & error & Lower bound & Upper bound \\
\hline 1 & I-II & $2032.16^{*}$ & 215.28 & 1451.95 & 2612.37 \\
2 & I-III & $3060.71^{*}$ & 192.98 & 2540.59 & 3580.82 \\
3 & II-III & $1028.54^{*}$ & 233.71 & 398.65 & 2540.59 \\
\hline
\end{tabular}

${ }^{*}$ The mean difference is significant at 0.01 level.

the south-west monsoon currents which impinge on the mountain ranges facing the coast. After the orographic precipitation over the wind-facing zone of the mountains, the clouds bear lesser moisture available for precipitation as it moves towards the Malanad zone. The subsequent declining trend in the rainfall amount can be attributed to this process. It may be noticed that, the Malanad zone is a fringe zone between the peaks and the leeward side of the ghats. Further, moving away from the Malanad zone, the leeward sides of the Western Ghats experience still lower rainfall due to depleting moisture content in the clouds.
Thus the analyses presented herein corroborates that the physical processes known to guide the rainfall distribution characteristics over the Western Ghats are quite valid for the study area. Besides, the study reveals that the maximum rainfall occurs on the windward side ahead of the geographical peak. This conforms with the result of the earlier studies where it was indicated that the maximum rainfall does not occur at the line of maximum height (Sarkar 1967). It is felt that a more detailed spatial analysis of rainfall with a shorter time scale is needed to obtain finer information relevant for micro-scale planning of agriculture activities. 


\section{References}

Bonell M 1997 The Eco-hydrology rehabilitation of degraded lands in Western Ghats, in Science \& Technology in Asia and The Pacific Co-operation for Development, UNESCO 1997, 123-130.

Lele S and Hegde G T 1997 Potential herblayer production and grazing effects in anthopogenic savanna-grasslands in the moist tropical forest of the Western Ghats of India; Tropical Grasslands 31 574-587.

Gadgil M, Hegde K M and Shetty K A B 1987 Uttara Kannada: A case study in hill area development; In: Karnataka: State of Environment Report 1985-86 (ed.) Saldanha C J 155-172.

Gadgil S, Gowri R and Yadumani 1988 Coherent rainfall zones: a Case study for Karnataka; Proceedings of Indian Academy of Sciences (Earth Planet Sci.) 97(1) 63-79.

Gunnell Y 1997a Relief and climate in South Asia: The influence of the Western Ghats on the current climate pattern of Peninsular India, Int. J. Climatol. 17 1169-1182.

Gunnell Y 1997b Comparative regional geography in India and West Africa. Soils, landforms and economic theory in agricultural development strategies; Geogr. J. 163(1) 38-46.

HYMOS 1999 Manuals for time series data analysis, National hydrology Project, Govt. of India.

Kulkarni B S and Damodara Reddy D 1994 The cluster analysis approach for classification of Andhra Pradesh on the basis of rainfall; Mausam 45(4) 325-332.

Patwardhan S K and Asnani G C 2000 Meso-scale distribution of summer monsoon rainfall near the Western Ghats (India); Int. J. Climatol. 20 575-581.

Sarkar R P 1967 Some modifications in a dynamical model of orographic rainfall; Monthly Weather Review $\mathbf{9 5}$ 673-684.

Raghvan K 1964 Influences of Western Ghats on monsoon rainfall; Ind. J. Met. Geophys. 15(4) 617-620.

Raju K V S 1981 Forest and Rain Report on Uttara Kannada; In: Major Dams - A Second look (eds) Gadgil M, Sharm L T and Sharma R, Environ, Cell, Gandhi Peace Foundation, New Delhi 99-101.

Ramachandran G and Banerjee A K 1983 The sub-divisional rainfall distribution across the Western Ghats during the southwest monsoon season; Mausam 32(2) 179-184. 